\title{
Research on Subcontractor Risk of EPC Hydropower Project in Vietnam
}

\author{
Dinh Bui ${ }^{*}$, Sy Hung $\mathrm{Mai}^{2}$, Huu Hai $\mathrm{Vu}^{2}$ \\ ${ }^{1}$ Department of Construction Management, Can Loc Committee, Ha Tinh, Vietnam \\ ${ }^{2}$ Department of Hydraulic Engineering and Construction, National University of Civil Engineering, Hanoi, \\ Vietnam \\ Email: ^Buidinhcl@gmail.com, hungms@nuce.edu.vn, haivu.huu@gmail.com
}

How to cite this paper: Bui, D., Mai, S.H. and Vu, H.H. (2019) Research on Subcontractor Risk of EPC Hydropower Project in Vietna. World Journal of Engineering and Technology, 7, 54-67.

https://doi.org/10.4236/wjet.2019.71003

Received: November 29, 2018

Accepted: December 23, 2018

Published: December 26, 2018

Copyright $\odot 2019$ by authors and Scientific Research Publishing Inc. This work is licensed under the Creative Commons Attribution International License (CC BY 4.0).

http://creativecommons.org/licenses/by/4.0/

\begin{abstract}
Engineering, procurement and construction (EPC) contracts are becoming the most popular form to undertake construction works on large-scale hydropower projects. The EPC general contractors in Vietnam have been coped with lots of difficulties during the construction phase of hydropower projects, resulting in significant schedule delays and cost overrun. One of the reasons is poor Subcontractors capacity. In order to overcome above, the current study attempts to research on identification and control Subcontractors risks of delay process of EPC hydropower project in Vietnam. Through summarizing international research achievements of previous researches relating on EPC hydropower projects combining with analysis characteristics of developing construction of EPC hydropower projects in Vietnam, the current study pointed out all kinds of subcontractor risk of delay process of EPC hydropower project in Vietnam; a questionnaire with 18 risk elements was designed and then delivered to experts in EPC hydropower project management area. Based on the risk model, 11 main risk elements were identified which can be categorized into 3 groups. Lastly, the current study proposed suggestions to reduce or avoid risks as well as approach to control risks. Furthermore, the findings of this study can be a good managerial reference for project management teams who are working in other countries that have similar economic and investment environment to Vietnam to get their EPC construction project completed on schedule, thus ensuring the benefits to the government, the investor, the contractor, and the parties involved.
\end{abstract}

\section{Keywords}

EPC Hydropower Project, Risk Analysis and Evaluation, Risk Control, Prevent Risks 


\section{Introduction}

In many countries, the capacity of Subcontractors is not good, especially in EPC contracted hydroelectricity. Subcontractors are the design, manufacture and supply of equipment, and subcontractors, etc. For instance, Doloi et al. identified the key factors impacting delay in Indian construction industry and established the relationship between the critical attributes for developing prediction models for assessing the impacts of these factors on not good quality and delay using questionnaire and personal interviews (Doloi, Sawhney, Iyer and Rentala, 2012) [1]. The authors therefore presented 7 most critical factors of not good quality and construction delay.

Regarding to EPC hydropower projects, despite of its subcontractors risk is also influenced by a variety of factors that are different for various countries [2] [3] [4], but previous researches have improperly focused on this topic. For instance, Wang et al. through evidences from Chinese constructions companies have quantitatively investigated the cause-effect relations among partnering, design management, and project outcomes and then concluded that design management is critical to project performances (Wang, Tang, Qi, Shen and Huang, 2015) [5]. However, the research does not show mutual interactions among design, procurement, and construction risks. Shi et al. also presented a comprehensive assessment of power projects overseas investment risks by establishing risk assessment model (Ge and Shi, 2014) [6]. Zhao et al. studied uncertainty runs through the whole process of the construction of the hydropower projects by analysing influencing factors of the risk of the hydropower projects (Zhao and Jia, 2011) [7], based on the analytic hierarchy process and the theory of intuitionistic fuzzy sets, an example which shows the practicality and validity of the method and also supplies scientific bases and references to the hydropower projects capitalists to make their investment decisions [8] [9]. Liu, D., and Song, H. (2010), analysed risk analysis and comprehensive evaluation of risks in EPC hydropower engineering [10]. Li, W. (2012), study on the risk management for international hydropower engineering of EPC program [11]. These researches merely presented most common assessment with respect to risk management of the projects, but mention unique characteristics of EPC hydropower projects and present risks that mainly influence on schedule delay of those kinds of projects. However, detailed and accuracy assessment on risks influencing on EPC hydropower projects is depended on characteristics and developing level of specific country [12] [13] [14].

On average, the study of Sub-contractors risk in EPC hydropower construction in Vietnam is very little. From there, find that the Research on assessment of subcontractors risks influence on schedule delay of EPC hydropower projects for every countries is indeed necessary.

The purpose of this study is to investigate and evaluate Subcontractors risks causing delay of EPC hydropower projects in Vietnam. In addition, the study also provided the recommendations for project practitioners to mitigate the im- 
pacts of those identified risks.

\section{Method Using in the Study}

In this study, we use checklist method to survey participants who have experiences in EPC hydropower construction in order to assess risks as well as impact level of them on constructions process [15] [16].

The method using in the study is based on the questionnaire including risk elements impact on EPC hydropower projects Vietnam. The entire researched process using in the study is detailed as shown in Figure 1.

The approach used in the study was based on a questionnaire survey, including the risk impact elements on Vietnamese EPC hydropower projects, and the entire process is detailed as shown in Figure 1. First, we established a questionnaire by referring to the previous literatures to determine the risk factors. Next, after obtaining the initial risk elements for the questionnaire, which was delivered to 25 experts in the EPC hydropower project management risk area, we collected the critical viewpoints of experts on the reliability of risk factors. From expert comments, the questionnaire was eventually revised to 18 risk elements, which can lead the schedule delay of EPC hydropower projects, consistent with practical conditions in Vietnam.

More specifically, 230 questionnaires were delivered to the participants who must have at least 30 years of relevant work experience on EPC hydropower projects in Vietnam. To analyse and assess the risk elements, we established the matrix with the size of $m \times n$ from collected data of the questionnaires, where $m$ is number of the participants and $n$ is number of risk elements in the survey. Finally, the risk, control and response were analysed and assessed.

\section{Results}

\subsection{Identification of the Risks}

In the questionnaire, as shown in Table 1, the risk delay elements of the construction are divided into five levels, such as very low, low, medium, high and very high based on the risk impact. Besides, these levels were translated to the numbers corresponding to $1,2,3,4$ and 5 , respectively.

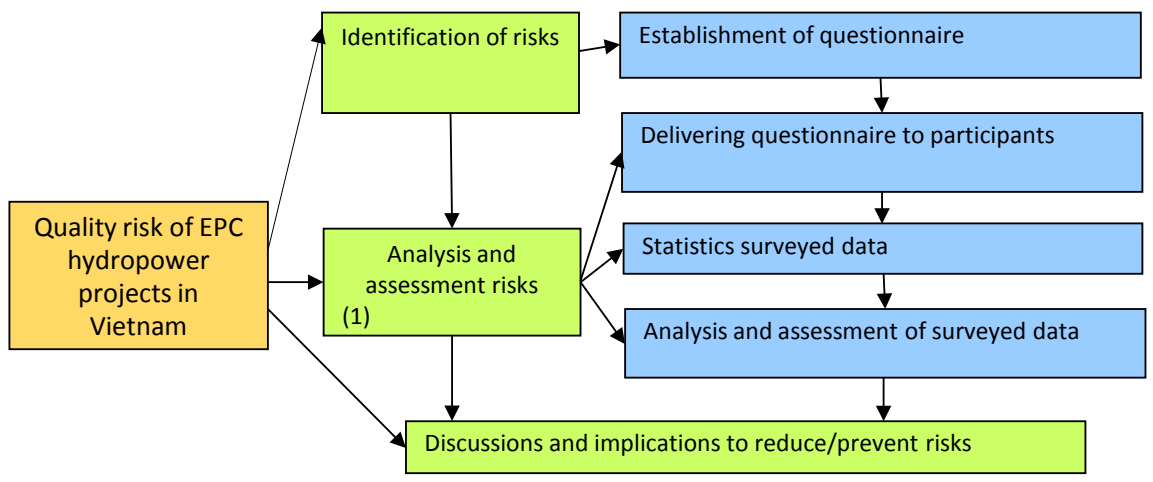

Figure 1. Schematic diagram of method used in the study. 
Table 1. Questionnaire using in the study.

\begin{tabular}{|c|c|c|c|c|c|c|c|}
\hline \multirow{2}{*}{ Risk groups } & \multirow{2}{*}{ Risk elements } & \multirow{2}{*}{$\begin{array}{l}\text { Expansions } \\
\text { of risks }\end{array}$} & \multicolumn{5}{|c|}{$\begin{array}{l}\text { Impact level to delay process } \\
\text { of constructions delays }\end{array}$} \\
\hline & & & $\begin{array}{l}\text { Very low } \\
\text { (1) }\end{array}$ & $\begin{array}{l}\text { Low } \\
(2)\end{array}$ & $\begin{array}{l}\text { Medium } \\
\text { (3) }\end{array}$ & $\begin{array}{l}\text { High } \\
(4)\end{array}$ & $\begin{array}{c}\text { Very } \\
\text { high (5) }\end{array}$ \\
\hline \multirow{6}{*}{$\begin{array}{c}\text { Risk of } \\
\text { Subcontractors design }\end{array}$} & $\begin{array}{l}\text { Risk due to poor Subcontractors survey (geology, topography, } \\
\text { hydrography) }\end{array}$ & $\mathrm{r} 1.1$ & & & & & \\
\hline & $\begin{array}{l}\text { Risks due to environmental impact assessment of } \\
\text { subcontractors }\end{array}$ & $\mathrm{r} 1.2$ & & & & & \\
\hline & Risk due to poor Subcontractors technical design & $\mathrm{r} 1.3$ & & & & & \\
\hline & Risk due to poor Subcontractors construction drawings & $\mathrm{r} 1.4$ & & & & & \\
\hline & Risk due to financial capacity of subcontractors & $\mathrm{r} 1.5$ & & & & & \\
\hline & Risks due to personnel capacity of subcontractors & r 1.6 & & & & & \\
\hline \multirow{7}{*}{$\begin{array}{l}\text { Risk of Subcontractors } \\
\text { materials, supplies, } \\
\text { equipment and } \\
\text { machines }\end{array}$} & Risk due to poor Subcontractors inspection & r 1.7 & & & & & \\
\hline & Risk due to poor Subcontractors materials & $\mathrm{r} 2.1$ & & & & & \\
\hline & Risk due to poor Subcontractors supplies & $\mathrm{r} 2.2$ & & & & & \\
\hline & $\begin{array}{l}\text { Risk due to poor Subcontractors Supply Mechanical and } \\
\text { electrical equipment }\end{array}$ & $\mathrm{r} 2.3$ & & & & & \\
\hline & Risk due to poor quality inspection of subcontractors & $\mathrm{r} 2.4$ & & & & & \\
\hline & Risk due to poor impart merchandise Subcontractors & $\mathrm{r} 2.5$ & & & & & \\
\hline & $\begin{array}{l}\text { Risk due to poor Subcontractors Supply construction } \\
\text { machines }\end{array}$ & r2.6 & & & & & \\
\hline \multirow{5}{*}{$\begin{array}{l}\text { Subcontractor of } \\
\text { construction }\end{array}$} & $\begin{array}{l}\text { Risk due to Subcontractors construction projects monitoring } \\
\text { team }\end{array}$ & r3.1 & & & & & \\
\hline & Risk due to poor sub-contractors of construction & $\mathrm{r} 3.2$ & & & & & \\
\hline & $\begin{array}{l}\text { Risks due to poorly subcontractor's machinery and } \\
\text { equipment }\end{array}$ & r3.3 & & & & & \\
\hline & Risks due to the capacity of workers of subcontractors is poor & $\mathrm{r} 3.4$ & & & & & \\
\hline & Risk due to subcontractor's finances is poor & r3.5 & & & & & \\
\hline \multirow{2}{*}{$\begin{array}{l}\text { Consequences } \\
\text { of risks }\end{array}$} & Prolong construction progress & $\mathrm{r} 4.1$ & & & & & \\
\hline & Increase in construction costs & $\mathrm{r} 4.2$ & & & & & \\
\hline
\end{tabular}

\subsection{Analysis and Assessment of the Risks}

Although 230 questionnaires were delivered to the participants in the progress of the survey, the number of questionnaires reached the requirement was 203. Therefore, $m=203$ and $n=18$ in the study (does not include the consequences of risk).

$$
X=\left[\begin{array}{cccc}
x_{11} & x_{12} & \ldots & x_{1 n} \\
x_{21} & x_{22} & \ldots & x_{2 n} \\
\ldots & \ldots & \ldots & \ldots \\
x_{m 1} & x_{m 2} & \ldots & x_{m n}
\end{array}\right]
$$

Hence, matrix $X=x_{i j}$ can be obtained in Equation (1), where $x_{i j}$ stands for the critical reviews given by the $i^{\text {th }}$ participant on the $f^{\text {th }}$ risk factor of Table 1 
$(i=1,2, \ldots, 203$, and $j=1,2, \ldots, 18)$. Moreover, we used matrix $X$ to verify the accuracy of the hypothesized risk elements based on the criteria calculated by SPSS and AMOS commercial software. In other words, the survey data were statistically used for calculation of estimation parameters to analyse and assess the risk factors. The weak impact of risk elements will be eliminated if the estimated parameters do not satisfy required standard, and the main risk elements delaying construction process of EPC hydropower projects in Vietnam will be preserved for further investigation.

1) Cronbach's Alpha coefficient to determine the risk factor reliability

Cronbach's Alpha coefficient that is in the interval from 0 to 1 was used to determine the risk element reliability. The higher value of $\alpha$ corresponds to the greater reliability of the hypothesized risk, for instance, $\alpha<0.6$ represents the hypothesis is unreliably relevant to the risk while for $0.8<\alpha<1$ the hypothesis should be highly reliable. In this study, we took the condition of $\alpha>0.6$ as the criteria to assess whether the hypothesized risk elements were reliable (Hair, 2009).

The calculated coefficients shown in Table 2, there are 24 exceedingly reliable risk elements since the Cronbach's alpha values are $\sim 0.75(\alpha>0.6)$ in the last column Cronbach's Alpha if Item Deleted. Hence, we neglected the risk elements including r1.2, r1.3, r1.7, r2.2, r2.5, r3.3, r3.6 as $\mu<0.3$ (Hair, 2009), where $\mu$ is the corrected item minus total correlation, and these risk elements can be ignored due to the weakness impact on the delay schedule. The results of coefficients $\alpha$ corresponding to hypotheses for the existence of the 11 risk elements are listed in Table 2.

2) Calculation and analysis discovery factors based on pattern matrix

Before simulation of SEM (Structural Equation Modelling), it is necessary to calculate and analyse the discovery factors to investigate the main factors including

Table 2. Cronbach's alpha coefficients of 3 factor and risks.

\begin{tabular}{cccc}
\hline Factor & $\begin{array}{c}\text { Cronbach's Alpha if } \\
\text { Item Deleted of factor }\end{array}$ & Risk & $\begin{array}{c}\text { Cronbach's Alpha if } \\
\text { Item Deleted of risks }\end{array}$ \\
\hline $\begin{array}{c}\text { Risk of Subcontractors design } \\
\text { (R1) }\end{array}$ & 0.786 & $\mathrm{r} 1.1$ & 0.743 \\
& & $\mathrm{r} 1.4$ & 0.756 \\
$\begin{array}{c}\text { Risk of Subcontractors } \\
\text { materials, supplies, equipment }\end{array}$ & 0.673 & $\mathrm{r} 1.6$ & 0.757 \\
and machines (R2) & & $\mathrm{r} 2.1$ & 0.747 \\
& & $\mathrm{r} 2.3$ & 0.755 \\
& & $\mathrm{r} 2.4$ & 0.749 \\
$\begin{array}{c}\text { Subcontractor of } \\
\text { construction (R3) }\end{array}$ & 0.861 & $\mathrm{r} 3.1$ & 0.751 \\
& & $\mathrm{r} 3.2$ & 0.747 \\
& & $\mathrm{r} 3.4$ & 0.726 \\
& & $\mathrm{r} 3.5$ & 0.724 \\
\hline
\end{tabular}


the observation variables. The discovery factors were analysed from the pattern matrix and value indicators, such as Kaiser-Meyer-Oklin (KMO), Bartlett examination $(\sigma)$, percentage of variance and coefficients of loading factor. The value of KMO is 0.783 indicative of that the survey data are statistically significant if $\mathrm{KMO} \geq 0.5$ and $\sigma<0.05$ (Hair, 2009).

Therefore, 3 main factors were chosen such as R1, R2 and R3 whose percentage of variance reached $52.68 \%$, higher than the standard value of $50 \%$, these results mean that the risks categorized into 3 groups is a reasonable hypothesis as shown in Table 3 and Table 4 (Gerbing and Anderson, 1988; Jabnoun and Hassan Al-Tamimi, 2003).

3) Analysis and verifying the combination of factors based on coefficients of the loading factor

Next, we used the AMOS commercial software for 3 assumed factors and 11 risk elements to calculate the standardized coefficients of the loading factor. If the coefficient is larger than 0.5 , which shows the assumed risk variables for the group of combined factors in a close relationship, the hypothesized risk variables have the largest effect on the factor group, as pointed out in SEM (see Figure 2).

4) The value calculation of $\chi^{2} / \mathrm{d} f, G F I, T L I, C F I, R M S E A$ to assure if the proposed model for the survey data is a reasonable design

The values of $\chi^{2} / \mathrm{d} f$, Goodness of Fit Index (GFI), Tucker Lewis Index (TLI), Comparative Fit Index (CFI) and Root Mean Square Error of Approximation (RMSEA) were used to estimate if the model is reliable. According to our estimation, the values of $\chi^{2} / \mathrm{d} f=1.070<3$, which reveal that the model is excellent for accordance with the survey data (Hair, 2009). In addition, the conditions of GFI $=0.955>0.9$, TLI $=0.992 \geq 0.9$ and CFI $=0.994>0.9$ indicate that the model for the survey data has statistics significance (Segars and Grover, 1993).

Table 3. Pattern matrix.

\begin{tabular}{|c|c|c|c|c|c|c|c|}
\hline \multirow{2}{*}{ Risk } & \multicolumn{7}{|c|}{ Factor } \\
\hline & 1 & 2 & 3 & 4 & 5 & 6 & 7 \\
\hline $\mathrm{r} 1.1$ & & 0.866 & & & & & \\
\hline r1.4 & & 0.684 & & & & & \\
\hline r1.5 & & 0.670 & & & & & \\
\hline r1.6 & & 0.558 & & & & & \\
\hline $\mathrm{r} 2.1$ & & & 0.530 & & & & \\
\hline $\mathrm{r} 2.3$ & & & 0.742 & & & & \\
\hline r2.4 & & & 0.736 & & & & \\
\hline r3.1 & & & & 0.679 & & & \\
\hline r3.2 & & & & 0.859 & & & \\
\hline r3.4 & & & & 0.854 & & & \\
\hline r3.5 & & & & 0.730 & & & \\
\hline
\end{tabular}


Table 4. Total variance explanation.

\begin{tabular}{cccccccc}
\hline \multirow{2}{*}{ Risks } & \multicolumn{3}{c}{ Initial Eigenvalues } & \multicolumn{3}{c}{$\begin{array}{c}\text { Extraction Sums of Squared } \\
\text { Loadings }\end{array}$} & $\begin{array}{c}\text { Rotation Sums } \\
\text { of Squared } \\
\text { Loadings }\end{array}$ \\
\cline { 2 - 7 } & Total & Variance\% & Cumulation\% & Total & Variance\% & Cumulation\% & Total \\
\hline 1 & 3.428 & 31.165 & 31.165 & 3.027 & 27.517 & 27.517 & 2.769 \\
2 & 2.294 & 20.851 & 52.017 & 1.844 & 16.766 & 44.283 & 2.067 \\
3 & 1.421 & 12.918 & 64.935 & 0.924 & 8.399 & 52.682 & 1.808 \\
4 & 0.819 & 7.448 & 72.382 & & & & \\
$\ldots$ & $\ldots$ & $\ldots .$. & $\ldots$. & & & & \\
10 & 0.336 & 3.055 & 97.956 & & & & \\
11 & 0.225 & 2.044 & 100.000 & & & & \\
\hline
\end{tabular}

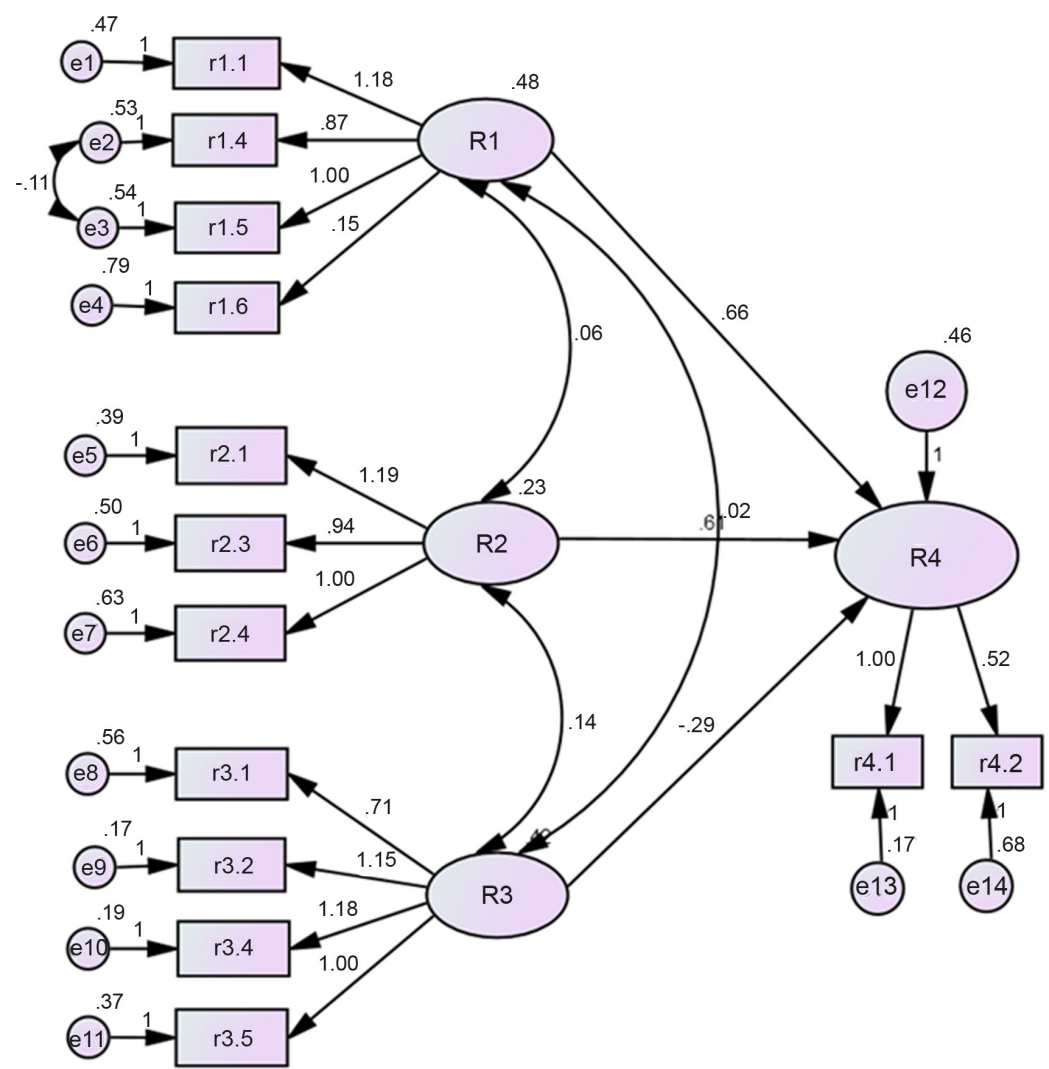

Chi-square $=62.083 ; \mathrm{df}=58$;

Chi-square/df=1.070;

GFI=.955; TLI=.992; CFI=.994;

RMSEA $=.019$

Figure 2. The structure of SEM and results assessment.

Otherwise RMSEA $=0.019<0.05$ is a significant index to assure if the proposed model is consistent with the standard model (Taylor, Sharland, Cronin and Bullard, 1993). These results allow us to conclude that the assessed result was exceptionally ideal and further indicate the proposed model for the survey data was 
the reasonable design.

\section{5) Discussions and evaluation on the parameters of the model}

The impacts of the risk elements on the risk factors were estimated through regression index, relationships among the risk elements were indicated by narrows in SEM model. The proposed risk elements are accepted if $\mathrm{P} \leq 0.05$, that is, the reliability is bigger than $95 \%$ (Cohen, 1977). We used the SEM and AMOS software to deal with the data to obtain the results of Standard Error (S.E.), Composite Reliability (C.R.), and Probability value (P) are given in Table 5.

The $\mathrm{P}$ values in Table 5 are less than 0.05 , which suggests that the reliability is larger than $95 \%$ of the assumed risk. Thus, the risk factors strongly influence on the schedule of the construction progress.

6) Results Summary

Through the analysis and testing, the authors synthesized is there are 11 main risk of Subcontractors into 3 factor groups to delaying the EPC hydropower construction progress of Vietnam in Table 6.

\subsection{Analysis, Discussions and Implications to Reduce/Prevent Risks}

Control each section of the project strictly: In bidding period, the technical tender of the general must allow adequate leeway for the design, equipment procurement and construction of implementation phase.

\subsubsection{Establishment Diagram of Subcontractors Risk Control for EPC Hydropower in Vietnam}

Establishment diagram of Subcontractors Risk control for EPC hydropower in Vietnam in Figure 3, Concurrently with Analysis of risks characteristics at Hydropower as per the mode of EPC contract in Vietnam, from then, to propose solutions for evasion and prevention of Subcontractors Risk control.

Based on the results obtaining in Table 6, finding of 11 risks; it could pave a way for risk manager, owner, and constructors that can aware about risk clearly, therefore could find proper strategy to deal with schedule delay of construction process of EPC hydropower project in Vietnam.

\subsubsection{Propose Implications to Deal with Some Main Risks in Order to Invent/Reduce Risks That Impact on Construction Progress of EPC Hydropower Project in Vietnam \\ 1) Risk due to Subcontractors construction projects monitoring team}

Table 5. The values of Regression weights: Estimate, S.E., C.R, P.

\begin{tabular}{|c|c|c|c|c|}
\hline $\begin{array}{l}\text { Assumed risks lead to consequent risk that extends } \\
\text { construction progress }\end{array}$ & Estimate & S.E. & C.R. & $\mathrm{P}$ \\
\hline Risk of Subcontractors design (R1) & 0.660 & 0.127 & 5.20 & $* * *$ \\
\hline $\begin{array}{l}\text { Risk of Subcontractors materials, supplies, equipment and } \\
\text { machines (R2) }\end{array}$ & 0.614 & 0.217 & 2.83 & 0.005 \\
\hline Subcontractor of construction (R3) & 0.290 & 0.124 & 2.35 & 0.019 \\
\hline
\end{tabular}

Note: ${ }^{* *}$ indicates that the value is less than 0.001 . 
Table 6. Summary 11 main risk of Subcontractors into 3 factor groups to delaying the EPC hydropower construction progress of Vietnam.

\begin{tabular}{|c|c|c|}
\hline Risk groups & Risk elements & $\begin{array}{l}\text { Expansions of } \\
\text { risks }\end{array}$ \\
\hline \multirow{4}{*}{ Risk of Subcontractors design } & $\begin{array}{l}\text { Risk due to poor Subcontractors survey (geology, } \\
\text { topography, hydrography) }\end{array}$ & $\mathrm{r} 1.1$ \\
\hline & $\begin{array}{l}\text { Risk due to poor Subcontractors construction } \\
\text { drawings }\end{array}$ & $\mathrm{r} 1.4$ \\
\hline & Risk due to financial capacity of Subcontractors & $\mathrm{r} 1.5$ \\
\hline & Risks due to personnel capacity of Subcontractors & r 1.6 \\
\hline \multirow{3}{*}{$\begin{array}{c}\text { Risk of Subcontractors } \\
\text { materials, supplies, equipment } \\
\text { and machines }\end{array}$} & Risk due to poor Subcontractors materials & $\mathrm{r} 2.1$ \\
\hline & $\begin{array}{l}\text { Risk due to poor Subcontractors Supply Mechanical } \\
\text { and electrical equipment }\end{array}$ & $\mathrm{r} 2.3$ \\
\hline & $\begin{array}{l}\text { Risk due to poor quality inspection of } \\
\text { subcontractors }\end{array}$ & $\mathrm{r} 2.4$ \\
\hline \multirow{4}{*}{ Subcontractor of construction } & $\begin{array}{l}\text { Risk due to Subcontractors construction projects } \\
\text { monitoring team }\end{array}$ & $\mathrm{r} 3.1$ \\
\hline & Risk due to poor sub-contractors of construction & $\mathrm{r} 3.2$ \\
\hline & $\begin{array}{l}\text { Risks due to the capacity of workers of } \\
\text { subcontractors is poor }\end{array}$ & r3.4 \\
\hline & Risk due to subcontractor's finances is poor & r3.5 \\
\hline
\end{tabular}

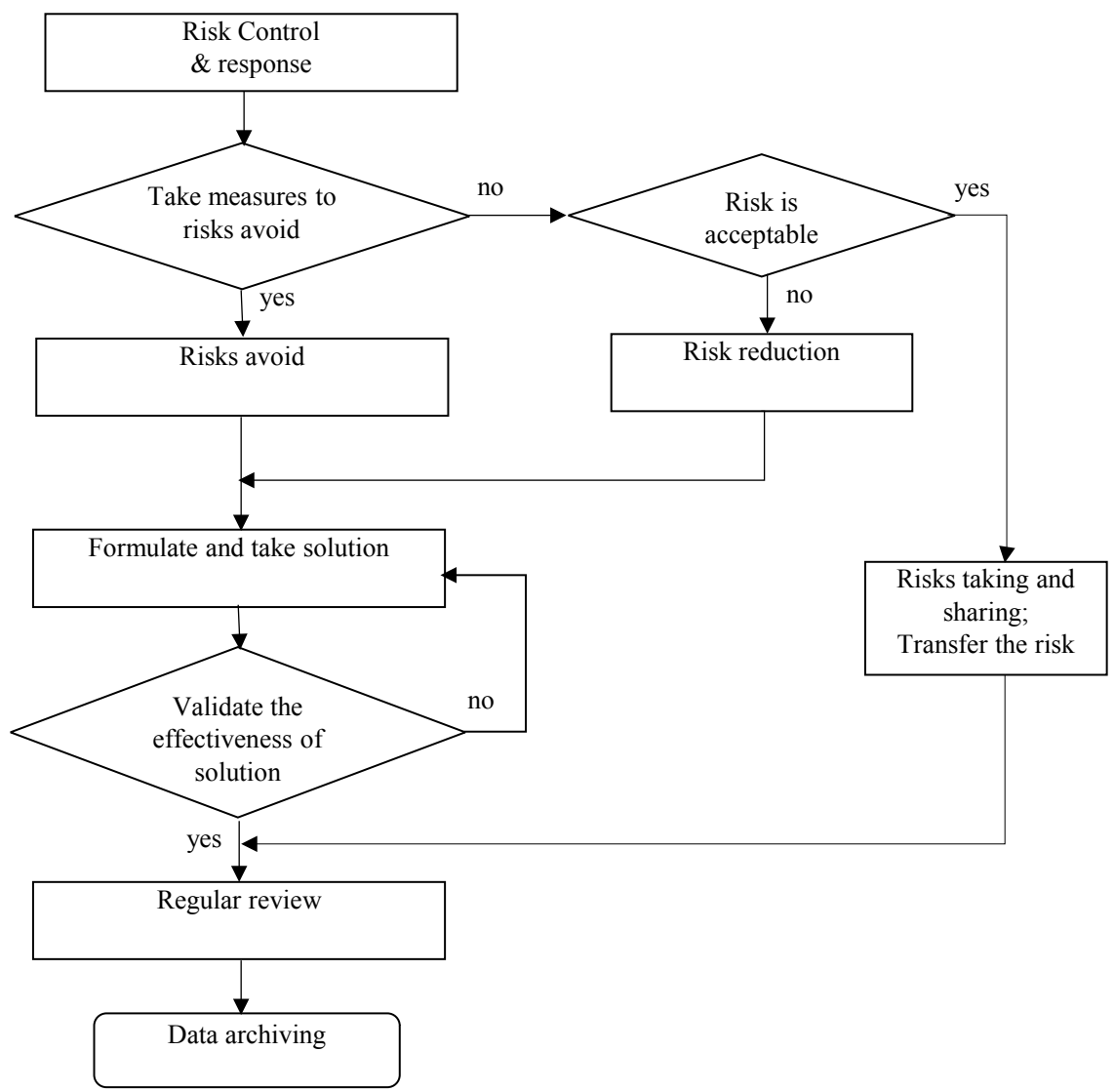

Figure 3. Risk control \& response diagram for EPC hydropower in Vietnam. 
To ensure project is not delayed due to this risk, the construction supervision contract must be assigned to capable units, having already implemented similar projects or of large scale. Employed supervisors should possess skilful in all aspects of the project, and continuously monitor all aspects of the construction. It is needed to attempt a massive fine for monitoring staffs who do or cooperate with contractor deliberately do illegal actions.

2) Risk of Subcontractors materials, supplies, equipment and machines

In the construction of hydropower as per EPC mode, there is a big quantum of commodities to be procured. In Vietnam, many local cargoes are not available but have to import such as: turbine, generator, automatic remote system, etc. Hence, the quality management is deemed to be one of the most important tasks and that is also very difficult. In order to avoid and prevent such kind of risk, all materials, spare parts, facilities to be used for the construction or technological items (to be called generally as "commodities") should be checked as per quality standard or design to know whether they conform or not before the application. Especially, all Subcontractors who are selected for the supply of commodities should be reputable with good products that confirmed by the market.

3) Risks due to delay of purvey equipment and machines

It is required to purchase and manufacture goods on a set schedule to serve the projects, specifically the goods which are unavailable in the host country and must be imported.

Especially, all Subcontractors who are selected for the supply of commodities should be reputable with good products that confirmed by the market. Both employer and commodity purchase contracts of EPC contractor and subcontractors must be clear in terms of reward and punishment for slow supply of goods. The government should have directions and create favorable conditions for the import of goods for projects.

In the construction of hydropower as per EPC mode, there is a high quantum of commodities to be procured. In Vietnam, many local cargoes are not available but have to import such as turbine, generator and automatic remote system. Hence, the quality management is deemed to be one of the most important and difficult tasks. In order to avoid and prevent such kinds of risk, all materials, spare parts and facilities used for the construction or technological items (generally called as "commodities") should be checked as per quality standard or design to know whether they conform or not before the application. Especially, all subcontractor who are selected for the supply of commodities should be reputable with good products that confirmed by the market.

4) Risk due to poor Subcontractors of construction

To avoid risk due to subcontractors, the subcontracts being employed should have substantial construction capacity. The Subcontractors should have financial capacity to carry out the project and a bank guarantee. Economic contract of EPC contractors and subcontractors must be fixed, clear, and has strict reward or punishment for progress. In the documents showing in the bid process, contractor should show capacity of subcontractors that the owner can have a com- 
prehensive assessment.

5) Risk due to installation and commissioning of equipment subcontracts

Owning to Vietnam still cannot product massive hydroelectric equipment, such as, turbine, dynamo, but importation. The installation and operation, therefore, face many issues. We thus recommend sell equipment company send capable and experience stuffs to construction cite to guide installation and operation properly.

To ensure the schedule of the project goes in time, production equipment using in the construction process should reach international standards. Installation Company of equipment must be highly qualified, and equipment manufacturing company must have professional technicians guiding the machines, equipment installation, and commissioning. General contract and subcontractors' equipment installation contract must be clear and strict in terms of payoff for the slow progress.

6) Risk due to technical design and construction drawings design

In order to prevent risks due to technical design, technical and construction draft designers being employed should have implemented the design of equivalent works or larger scale construction. The design must comply with the work scale as approved by the investor and the authorities. The owner should carefully investigate document at initial establishment of the investment project. The inspection must implement in detail of the design drawings of the technical and construction design documents.

Owner may demand some design changes during construction, but to a limit having no adverse effect on the activities on the critical path. To reduce risks due to constructions drawings, changes of design, which includes contract price adjustment equivalent to the content and changes in work volume, should be attached with the legal documents then delivered to the investor. General contractors' design contracts with the design company must be clear, and be aware of there will be a strict payoff for slow progress.

It is required to abide by all national designated standards as well as other regulations of Vietnam. Moreover, the design company should be authorized on its capability by Certificate in Electric Practice.

Delay in site delivery, approving design documents, and progress payments are delay factors caused by owner. Site should be delivered as soon as possible after project is awarded. Approval of design documents should not be delayed, since it could delay the progress of work. Progress payments should be made on time to contractor in order to finance the work.

7) Risk due to geology, topography and hydrography

To avoid risks due to natural environmental conditions, the constructor should appoint an experienced survey company, with an equivalent scale or larger. The investor and survey document designing unit shall appoint qualified and skilled staffs to ensure the quality of surveyed data. Otherwise, it is required to employ an independent inspection unit to detect errors in survey results on a set schedule. Monitoring unit, investor, and general contractor should supervise 
the environmental conditions during the construction process. Therefore, it allows construction unit can take a prompt response to any unforeseen issues that may arise in further.

\section{Conclusions}

Subcontractor is the first important factor for any EPC General contractor who involve in the hydropower project execution. The EPC contractor should manage well of the project in the stage of construction progress which is deemed to be a core mission project risks management and that is also might be the main factor which decides the success or failure of such project.

Using surveyed method combined with statistical analysis, the study investigates potential risks influence on schedule delay of EPC hydropower projects in Vietnam. Findings in the study includes following achievements:

1) Identification 11 main risks of Subcontractors that impact on construction progress of EPC hydropower construction projects.

2) Based on those risks the study has analyzed, and evaluated carefully the Subcontractors risks to determine 3 group causes leading to the delay of EPC hydropower projects in Vietnam.

3) Discussions and implications are to reduce/prevent risks.

Subcontractor management in Construction stage is an important part of hydropower project management, which required the subcontracts to abide by the technical contract to develop the quality management system as well as quality system documentation with transparent quality target. Moreover, always ensure the schedule as required.

\section{Looking Ahead}

In this study, the author mentioned the findings of major risks and proposed measures to control them. The risk assessment and control constructed on the basis of survey data with experts, so the main source of data depends on the subjective experts' opinions. Therefore, it is proposed further studies on the following aspects:

1) In the aspect of engineering risk management information system, it is necessary to develop data collection and processing methods and standards, and to establish a risk-related information system in the construction process which can be adjusted to the specific conditions of each EPC hydropower project.

2) It is needed to develop engineering risk management information system software to improve the implementation of project risk information management, and to extend the scope of management applications. The management must be adapted to all types of project risk management with different specific characteristics and risks.

\section{Conflicts of Interest}

The authors declare no conflicts of interest regarding the publication of this paper. 


\section{References}

[1] Doloi, H., Sawhney, A., Iyer, K. and Rentala, S. (2012) Analysing Factors Affecting Delays in Indian Construction Projects. International Journal of Project Management, 30, 479-489. https://doi.org/10.1016/j.ijproman.2011.10.004

[2] Faridi, A.S. and El-Sayegh, S.M. (2006) Significant Factors Causing Delay in the UAE Construction Industry. Construction Management and Economics, 24, 1167-1176. https://doi.org/10.1080/01446190600827033

[3] Sambasivan, M. and Soon, Y.W. (2007) Causes and Effects of Delays in Malaysian Construction Industry. International Journal of Project Management, 25, 517-526. https://doi.org/10.1016/j.ijproman.2006.11.007

[4] Gündüz, M., Nielsen, Y. and Özdemir, M. (2012) Quantification of Delay Factors Using the Relative Importance Index Method for Construction Projects in Turkey. Journal of Management in Engineering, 29, 133-139. https://doi.org/10.1061/(ASCE)ME.1943-5479.0000129

[5] Wang, T., Tang, W., Qi, D., Shen, W. and Huang, M. (2015) Enhancing Design Management by Partnering in Delivery of International EPC Projects: Evidence from Chinese Construction Companies. Journal of Construction Engineering and Management, 142, Article ID: 04015099. https://doi.org/10.1061/(ASCE)CO.1943-7862.0001082

[6] Ge, S.J. and Shi, A.N. (2014) Construction of the Factors Affecting China. Proc. Applied Mechanics and Materials, Trans Tech Publ., 672-674.

[7] Zhao, E. and Jia, X. (2011) Research on the Method of Evaluating Risks of Hydropower Project. Proceedings of 2011 IEEE International Conference on Computer Science and Service System (CSSS), Nanjing, 27-29 June 2011, 1653-1655.

[8] McCord, J., McCord, M., Davis, P.T., Haran, M. and Rodgers, W.J. (2015) Understanding Delays in Housing Construction: Evidence from Northern Ireland. Journal of Financial Management of Property and Construction, 20, 286-319. https://doi.org/10.1108/JFMPC-07-2015-0028

[9] Bagaya, O. and Song, J. (2016) Empirical Study of Factors Influencing Schedule Delays of Public Construction Projects in Burkina Faso. Journal of Management in Engineering, 32, Article ID: 05016014. https://doi.org/10.1061/(ASCE)ME.1943-5479.0000443

[10] Liu, D. and Song, H. (2010) Risk Analysis and Comprehensive Evaluation of Risks in EPC Hydropower Engineering. Water Sciences and Engineering Technology, 1, 74-76.

[11] Li, W. (2012) Study on the Risk Management for International Hydropower Engineering of EPC Program. Doctor Thesis, Dalian University of Technology, Dalian.

[12] Elawi, G.S.A., Algahtany, M., Kashiwagi, D. and Sullivan, K. (2015) Major Factors Causing Construction Delays in Mecca. Journal for the Advancement of Performance Information \& Value, 7, 1-11.

[13] Santoso, D.S. and Soeng, S. (2016) Analyzing Delays of Road Construction Projects in Cambodia: Causes and Effects. Journal of Management in Engineering, 32, Article ID: 05016020. https://doi.org/10.1061/(ASCE)ME.1943-5479.0000467

[14] Marzouk, M.M. and El-Rasas, T.I. (2014) Analyzing Delay Causes in Egyptian Construction Projects. Journal of Advanced Research, 5, 49-55. https://doi.org/10.1016/j.jare.2012.11.005

[15] Taylor, S.A., Sharland, A., Cronin, J.J. and Bullard, W. (1993) Recreational Service Quality in the International Setting. International Journal of Service Industry Man- 
agement, 4, 68-86. https://doi.org/10.1108/09564239310044316

[16] Cohen, J. (1977) Statistical Power Analysis for the Behavioral Sciences (Revised Edition). Academic Press, New York. 